\title{
Brazilian donkey slaughter and exports from 2002 to 2019
}

\section{Abate e exportação de jumentos no Brasil de 2002 a 2019}

\author{
Mariana Bombo Perozzi Gameiro ${ }^{1}$ (D); Vanessa Theodoro Rezende ${ }^{2}$; Adroaldo José Zanella ${ }^{1}$ \\ ${ }^{1}$ Universidade de São Paulo, Faculdade de Medicina Veterinária e Zootecnia, Departamento de Medicina Veterinária Preventiva e Saúde Animal, \\ Pirassununga - SP, Brazil \\ ${ }^{2}$ Universidade de São Paulo, Faculdade de Medicina Veterinária e Zootecnia, Departamento de Nutrição e Produção Animal, Pirassununga - SP, Brazil
}

\begin{abstract}
The international demand for donkeys has increased sharply in recent years, motivated by China's growing interest in producing ejiao (a traditional medicine made from donkey skin) and, in a smaller proportion, donkey meat. Since the Chinese donkey population dropped by $75.4 \%$ in the past 25 years, the country has searched for supply in the international market, mainly in Africa and South America. Aiming to understand the participation of Brazil in this scenario, this paper presents and discusses official data on donkey slaughter and donkey meat and skin exports in Brazil from 2002 to 2019. After the recent news reports of donkey trade-related mistreatment in the Brazilian Northeast, the issue has attracted attention from public authorities, the media, and civil society, but it lacked a quantitative description that could give a tangible dimension to the situation. The interpretation of these data is made with the collaboration of qualitative research methods, emphasizing some aspects of human-animal relations.
\end{abstract}

Keywords: Equids. Trade. Animal welfare. Human-animal relations.

\section{RESUMO}

A demanda internacional por jumentos vem aumentando drasticamente nos últimos anos, motivada pelo crescente interesse da China em produzir ejiao (medicamento tradicional feito a partir da pele do animal) e, em menor proporção, carne de jumento. Devido à redução de $75,4 \%$ na população de jumentos chineses nos últimos 25 anos, o país tem buscado se abastecer no mercado internacional, principalmente na África e na América do Sul. Com o objetivo de compreender a participação do Brasil neste cenário, este artigo apresenta e discute dados oficiais sobre abate de jumentos e exportação de carne e pele de jumentos no Brasil, de 2002 a 2019. Após a recente divulgação de notícias sobre maustratos relacionados ao comércio de jumentos no Nordeste do Brasil, o assunto tem atraído a atenção do poder público, da mídia e da sociedade civil, mas ainda carecia de uma descrição quantitativa que pudesse fornecer uma dimensão tangível à situação. A interpretação desses dados é feita com a colaboração de métodos de pesquisa qualitativa, enfatizando algumas facetas das relações humano-animais.

Palavras-chave: Equídeos. Comércio. Bem-estar animal. Relações humano-animais.

\section{Correspondence to:}

Mariana Bombo Perozzi Gameiro

Universidade de São Paulo, Faculdade de Medicina Veterinária

e Zootecnia, Departamento de Medicina Veterinária

Preventiva e Saúde Animal

Av. Duque de Caxias Norte, 225, Campus Fernando Costa

CEP: 13635-900, Pirassununga - SP, Brazil

e-mail: marianaperozzi@gmail.com

Received: September 10, 2020

Approved: January 18, 2021

How to cite: Gameiro MBP, Rezende VT, Zanella AJ. Brazilian donkey slaughter and exports from 2002 to 2019. Braz J Vet Res Anim Sci. 2021;58(special issue):e174697. https://doi.org/10.11606/issn.1678-4456.bjvras.2021.174697

\section{Introduction}

Led by the Chinese pharmaceutical industry, the international demand for donkeys has increased sharply in recent years. What could be classified by some as an uncommon business has proven to have a large tradition in this eastern country. The donkey hide gelatin is the raw material for the production of ejiao, a traditional Chinese remedy that has been used for over 3,000 years. Collagen is believed to be the main active component in ejiao (Colla corii asini - CCA), with claimed therapeutic properties linked to blood nourishing, immune response optimization, metabolic balance improvement, senescence delay, and the treatment of gynecologic diseases (Li et al., 2017). 
The potential effectiveness of CCA in practice would have led to more consumer awareness of its benefits, increasing the demand and, consequently, its yearly production and market sales, which reached approximately 6,000 tons and US\$ 1.5 billion, respectively, in 2015 (Li et al., 2017). Eijao production has had an annual growth of more than $20 \%$. About $90 \%$ of China's ejiao products are made in Shandong Province with imported donkey skin (Xinhua News Agency, 2017) from countries with no established culture or business models to explore this type of product.

The consequence of the growing demand for ejiao is high and rapidly increasing prices, as well as a shortage of donkey hide supply (Li et al., 2017; The Donkey Sanctuary, 2019), worsened by donkeys low fertility rate and the long gestation period. Ejiao's industrial insiders report that the price of a single hide has grown from 20 yuan in 2000 to about 3,000 yuan in late December 2017 (Xinhua News Agency, 2017). In China, the donkey population decreased from 10.89 million in 1994 to 2.68 million animals in 2018, a drop of $75.4 \%$ (Food and Agricultural Organization of the United Nations, 2020).

This has put strong pressure on donkey populations globally and led to theft and illegal trade in donkeys, resulting in concerns for donkey welfare and the livelihoods of those who rely on donkeys (Bennett \& Pfuderer, 2020; The Donkey Sanctuary, 2019). Most recent data indicate that the global donkey population was around 50.4 million in 2018 (Food and Agricultural Organization of the United Nations, 2020).

To supply the ejiao market, donkeys have been mainly sourced from Africa and South America. In Africa, donkeys are particularly important as working animals, used for many purposes from land cultivation to transport of materials and people. The concern about the impact of animal and animal products exports on the local economy and local population led several African governments to restrict these exports, i.e. Burkina Faso, Ghana, Uganda, Tanzania, Niger, Nigeria, Mali, and Senegal (The Donkey Sanctuary, 2019).

In Brazil, donkey slaughter is currently authorized, after a ban declared at the end of 2018 was lifted 10 months later, in the state of Bahia, the only state that formally signed a trade agreement with the Chinese government for donkey skin and meat exports. Differently from most African countries, in Brazil, the mechanization of agriculture and the replacement of donkeys by motorized vehicles (Salles et al., 2013) has reduced donkeys' utility value as a working animal in the past 20 years. The situation is well-known in other countries, especially in developed ones. In Europe, the mechanization in agriculture and transport has led the number of donkeys to decrease by $80 \%$ since the middle of the last century (Camillo et al., 2018). With no attention devoted to the breeding selection and biodiversity conservation, most of the European donkey breeds are now threatened with extinction (Camillo et al., 2018). Over $85 \%$ of the world's equids live in developing countries (Burn et al., 2010).

In Brazil, the reduction in donkey economic use facilitates their abandonment, which contributes to the increasing presence of roaming donkeys on roads (Gameiro et al., under review), constituting a source of free or low-cost animals to export, with disregard for donkey welfare or even sanitary conditions. In Brazil, the animal population decreased from 1.31 million donkeys in 1994 to 822,000 donkeys in 2018, down by $37.2 \%$ according to Food and Agricultural Organization of the United Nations (2020).

Brazil hosts three types of donkeys: (1) Northeast (ecotype) donkey, a class of highly rustic animals adapted to the adverse conditions of the Brazilian semiarid region; (2) Brazilian donkey, brought from Italy, with a close genetic relationship to African donkeys, and (3) Pêga donkey of Iberian origin, a special type of donkey developed mainly in the state of Minas Gerais for use in the mining industry (Carneiro et al., 2018). In this paper, we refer to donkeys in Brazil or Brazilian donkeys in general, without distinguishing among the three types. Even so, the Northeast donkey is the most threatened one in terms of inadequate welfare potentially associated with trade and slaughter.

In this context, this paper aims to present and discuss official data on donkey slaughter and donkey products exports in Brazil from 2002 to 2019. After the recent recurrent news reports of donkey mistreatment situations in the Brazilian Northeast (i.e. Suarez, 2019), the subject has attracted attention from public authorities, the media, and civil society, but it lacked an analysis that could give a tangible dimension to the situation.

\section{Materials and Methods}

For the quantitative (descriptive) approach of this study, slaughter data were collected for donkeys, horses, and mules from 2002 to 2019 at the Brazilian Ministry of Agriculture, Livestock and Supply (MAPA)'s SIGSIF database, provided by the Secretary of Animal and Plant Health (SDA). This period was chosen due to official data availability. Information about export-approved equid slaughterhouses was obtained at the same data system in June 2020.

Data regarding the Brazilian exports of live donkeys, equids meat, and equids raw hides and skins were collected at the 
Ministry of Industry, Foreign Trade and Services (MDIC)'s ComexStat database. It covered the period from 2002 to 2019, and product specifications follow the classification adopted by the Mercosur Common Nomenclature (NCM) ${ }^{1}$. "Equids" refer to data on donkeys, mules, and horses together, when the source of information does not dissociate them.

Averages, proportions and variations were calculated by the authors; graphics and figures were generated with the Power BI Microsoft software (2020).

The interpretation of these data was carried out with the collaboration of qualitative research methods, particularly document analysis (press news and reports) (Bowen, 2009). The aim was to improve the comprehension of the context and establish some relationships between numbers and facts.

Material on the historical perspective associated with the establishment of the donkey slaughter industry and export in Brazil was carried out by the first author through interviews and systematic review of local (Northeast), national and international press (approved by FZEA/USP Research Ethics Committee on Humans under the register 3.806.505).

\section{Results and Discussion}

Table 1 presents official data on donkeys, horses, and mules slaughter by state in Brazil from 2002 to 2019. It is important to highlight that these data refer to slaughterhouses registered within the Federal Inspection Service (SIF) of the Brazilian Department of Inspection of Animal Products (DIPOA); they are formally subjected to systematic veterinary/sanitary inspection and are authorized to trade at the national and international levels. The slaughterhouses whose products are only sold at inter-municipal or interstate levels are not covered by these statistics.

According to Table 1, Bahia is the state with the highest number of slaughtered donkeys in the last two decades, because it holds the largest donkey population (Queiroz et al. 2021) and, also, because of the trade agreements that are going to be described. The state officially registers the slaughter of 86,608 donkeys during the analyzed period, with occurrences in the year 2009 and from 2017 onwards. Animals come from all of the Northeastern regions to be slaughtered in Bahia. Minas Gerais ranks second, with a relatively steady and high number of donkeys annually slaughtered, totaling

\footnotetext{
NCM codes considered for "live donkeys": 01012000; 01013000; 01019000; 01019090 and 01011090 . NCM codes considered for "equids meat": 02050000 and 02109930. NCM codes considered for "equids raw hides and skins": 41041119; 41041129; 41044990; 41041990; 41044190; 41079190; 41079290; 41014010; 41014020; 41014030; 41079990; 41071990; 41071290; 41043190; 41071190; 41043990 and 41042900 (Brasil, 2020b).
}

35,035 donkeys in the two decades under analysis. The state of Minas Gerais has a strong tradition in breeding donkeys to produce hybrids (mules), but it does not breed and raise donkeys with meat or hide purposes. Rio Grande do Sul keeps the slaughter rate relatively constant, with 8,616 donkeys slaughtered in the period. Equally regular is the slaughter in Parana, but on a lower scale, 1,426 animals were slaughtered in the period. Goias slaughtered 3,569 donkeys, concentrated in the years 2004 and 2005. It is worth mentioning that the recent possibility of making a quick profit with the donkey and donkey products trade engendered illegal slaughters reported all over the Northeast region (i.e. G1 PE, 2017). However, these statistics are not covered by the present paper.

Table 2 and Figure 1 show the total number of donkeys, horses, and mules slaughtered in Brazil from 2002 to 2019, according to official records (SIF approved facilities). On average, 4,825 heads of donkeys were slaughtered per year between 2002 and 2010, with a peak of 11,941 animals in 2005 and the lowest reported number of 321 in 2003. The years of 2008 and 2009 also registered relatively high numbers (4,529 and 3,782, respectively), with a significant drop in 2010. The decade of 2010 starts with extremely low numbers (from 30 to 80 slaughters per year between 2011 and 2014, an average of 46); then rising to an average of 1,435 per year in 2015 and 2016; before jumping to 26,127 donkeys slaughtered in 2017 and 62,622 in 2018. Slaughters dropped to 25 animals in 2019 when the activity was banned in the state of Bahia. On average, the first half of the decade (2010-2015) had 355 donkeys slaughtered per year, while in the second half, this number increased by $5,066 \%$, to 18,329 animals. Figure 2 shows the proportion of donkeys slaughtered by year in Brazil.

The historical perspective described below, collected systematically during the development of this work, helps to explain the fluctuation of numbers in the presented data. In May 2004, it was reported that the state of Ceara would begin the industrial slaughter and export of donkey, horse, and mule meat to countries like Belgium, the Netherlands, and Japan. The project was to ship about 250 tons of meat from a slaughterhouse located at Santa Quitéria (Diário do Nordeste, 2004). The company responsible for the business had previously run an equids slaughterhouse in the state of Minas Gerais and explained that Ceara was chosen because of the large supply of roaming donkeys available (Fernandes, 2004). Animals would be sourced from roads and the stocks of public institutions responsible for the capture of donkeys on federal and state roads (like the National Department of Roads/DERT, Federal Road 
Table 1 - Slaughter of equids in Brazil, by state, from 2002 to 2019

\begin{tabular}{|c|c|c|c|c|}
\hline Year & State & Donkeys & Horses & Mules \\
\hline \multirow{5}{*}{2002} & BA & - & - & - \\
\hline & GO & - & - & - \\
\hline & MG & - & - & - \\
\hline & PR & 46 & 10289 & 37 \\
\hline & RS & 7761 & 38174 & - \\
\hline \multirow{5}{*}{2003} & BA & - & - & - \\
\hline & GO & - & - & - \\
\hline & MG & 158 & 28232 & 971 \\
\hline & PR & 135 & 74043 & 1446 \\
\hline & RS & 19 & 41797 & - \\
\hline \multirow{5}{*}{2004} & BA & - & - & - \\
\hline & GO & 3129 & 6021 & 86 \\
\hline & MG & 3334 & 40894 & 1697 \\
\hline & PR & 84 & 107704 & 2072 \\
\hline & RS & 71 & 39980 & 5 \\
\hline \multirow{5}{*}{2005} & BA & - & - & - \\
\hline & $\mathrm{GO}$ & 440 & 610 & 12 \\
\hline & MG & 11432 & 70660 & 3081 \\
\hline & PR & 53 & 85088 & 2342 \\
\hline & RS & 16 & 36108 & - \\
\hline \multirow{5}{*}{2006} & BA & - & - & - \\
\hline & GO & - & - & - \\
\hline & MG & 5311 & 40244 & 2171 \\
\hline & PR & 87 & 71551 & 2599 \\
\hline & RS & 116 & 32316 & - \\
\hline \multirow{5}{*}{2007} & BA & - & - & - \\
\hline & GO & - & - & - \\
\hline & MG & 1934 & 26101 & 1818 \\
\hline & PR & 60 & 62461 & 1737 \\
\hline & RS & 5 & 29303 & - \\
\hline \multirow{5}{*}{2008} & BA & - & 8 & - \\
\hline & GO & - & - & - \\
\hline & MG & 4372 & 25652 & 1612 \\
\hline & PR & 45 & 32585 & 2253 \\
\hline & RS & 112 & 29151 & - \\
\hline \multirow{5}{*}{2009} & BA & 2496 & 9260 & 792 \\
\hline & GO & - & - & - \\
\hline & MG & 951 & 14488 & 1362 \\
\hline & PR & 58 & 22822 & 1895 \\
\hline & RS & 277 & 25189 & 546 \\
\hline \multirow{5}{*}{2010} & BA & - & - & - \\
\hline & GO & - & - & - \\
\hline & MG & 894 & 13904 & 1313 \\
\hline & PR & - & 3397 & 344 \\
\hline & RS & 29 & 10441 & 26 \\
\hline \multirow{5}{*}{2011} & BA & - & - & - \\
\hline & GO & - & - & - \\
\hline & MG & 22 & 8406 & 848 \\
\hline & PR & - & - & - \\
\hline & RS & 8 & 9555 & 61 \\
\hline \multirow{5}{*}{2012} & BA & - & - & - \\
\hline & GO & - & - & - \\
\hline & MG & 4 & 5540 & 642 \\
\hline & PR & 49 & 5327 & 350 \\
\hline & $\mathrm{RS}$ & 27 & 9163 & 31 \\
\hline
\end{tabular}

Source: Elaborated by authors, with data from Brasil (2020a). 
Table 1 - Continued...

\begin{tabular}{|c|c|c|c|c|}
\hline Year & State & Donkeys & Horses & Mules \\
\hline \multirow{5}{*}{2013} & $\mathrm{BA}$ & - & - & - \\
\hline & GO & - & - & - \\
\hline & MG & - & - & - \\
\hline & PR & 15 & 4391 & 418 \\
\hline & RS & 21 & 9481 & 68 \\
\hline \multirow{5}{*}{2014} & BA & - & - & - \\
\hline & GO & - & - & - \\
\hline & MG & - & 47 & 38 \\
\hline & PR & 12 & 7793 & 755 \\
\hline & RS & 26 & 9334 & 18 \\
\hline \multirow{5}{*}{2015} & $\mathrm{BA}$ & - & - & - \\
\hline & GO & - & - & - \\
\hline & MG & 730 & 6295 & 596 \\
\hline & PR & 782 & 3775 & 234 \\
\hline & RS & 78 & 11450 & 6 \\
\hline \multirow{5}{*}{2016} & BA & - & - & - \\
\hline & $\mathrm{GO}$ & - & - & - \\
\hline & MG & 1261 & 11161 & 1213 \\
\hline & PR & - & - & - \\
\hline & RS & 20 & 11767 & 9 \\
\hline \multirow{5}{*}{2017} & BA & 21562 & 25 & - \\
\hline & GO & - & - & - \\
\hline & MG & 4552 & 3561 & 546 \\
\hline & PR & - & - & - \\
\hline & RS & 13 & 10413 & 19 \\
\hline \multirow{5}{*}{2018} & $\mathrm{BA}$ & 62548 & 708 & 1 \\
\hline & GO & - & - & - \\
\hline & MG & 73 & 4089 & 566 \\
\hline & PR & - & - & - \\
\hline & RS & 1 & 12439 & 48 \\
\hline \multirow{5}{*}{2019} & BA & 2 & 17793 & 3 \\
\hline & GO & - & - & - \\
\hline & MG & 7 & 2343 & 226 \\
\hline & PR & - & - & - \\
\hline & $\mathrm{RS}$ & 16 & 12658 & 42 \\
\hline
\end{tabular}

Source: Elaborated by authors, with data from Brasil (2020a).

Policies, Zoonosis Centers, etc.) (Fernandes, 2004; Diário do Nordeste, Ceará..., 2004). The owner of the slaughterhouse stated to the press that this would prevent animals from traveling three days to the state of Minas Gerais. It would also prevent animals from starving to death, as previously happened, as owners simply abandoned (or even killed) donkeys once they became obsolete with the end of animal traction. The slaughter would, therefore, represent a more sensible treatment of animals, which would compensate for the potential cultural resistance to the activity (Diário do Nordeste, Ceará..., 2004). Protests from many NGOs led by Ceara's UIPA (International Union for Animal Protection) resulted in the closure of Santa Quitéria's slaughterhouse in 2007 (Leitão, 2016).

In February 2012, a trade agreement was signed between Brazil and China, represented, respectively, by the
Ministry of Agriculture, Livestock, and Supply (MAPA) and the General Administration of Quality Supervision, Inspection, and Quarantine (AQSIQ), for the export of donkey meat and skin, without precisely indicating when exports would begin. The Brazilian Ministry of Foreign Affairs confirmed that the bilateral agreement took place during a meeting of the "Chinese-Brazilian High-Level Concertation and Cooperation Commission" (COSBAN), the main mechanism for diplomatic and trade relations between the two countries. The Ministry of Foreign Affairs informed that Brazil was not a producer of donkey edible meat and hides, but animals would be slaughtered in the country and the processed products would be exported (NE10, 2012). It is reported that Chinese investors had discussions with politicians and farmers in 2011, from Bahia to Rio Grande do Norte, to assure the export of 
Table 2 - The number of equids slaughtered in Brazil from 2002 to 2019

\begin{tabular}{|c|c|c|c|c|c|c|c|c|}
\hline & DONKEYS & $\begin{array}{c}\text { Annual } \\
\text { variation (\%) }\end{array}$ & HORSES & $\begin{array}{c}\text { Annual } \\
\text { variation (\%) }\end{array}$ & MULES & $\begin{array}{c}\text { Annual } \\
\text { variation (\%) }\end{array}$ & TOTAL & $\begin{array}{c}\text { Annual } \\
\text { variation (\%) }\end{array}$ \\
\hline 2002 & 7807 & & 48463 & & 37 & & 56307 & \\
\hline 2003 & 312 & $-96 \%$ & 144072 & $197 \%$ & 2417 & $6432 \%$ & 146801 & $161 \%$ \\
\hline 2004 & 6618 & $2021 \%$ & 194599 & $35 \%$ & 3860 & $60 \%$ & 205077 & $40 \%$ \\
\hline 2005 & 11941 & $80 \%$ & 192466 & $-1 \%$ & 5435 & $41 \%$ & 209842 & $2 \%$ \\
\hline 2006 & 5514 & $-54 \%$ & 144111 & $-25 \%$ & 4770 & $-12 \%$ & 154395 & $-26 \%$ \\
\hline 2007 & 1999 & $-64 \%$ & 117865 & $-18 \%$ & 3555 & $-25 \%$ & 123419 & $-20 \%$ \\
\hline 2008 & 4529 & $127 \%$ & 87396 & $-26 \%$ & 3865 & $9 \%$ & 95790 & $-22 \%$ \\
\hline 2009 & 3782 & $-16 \%$ & 71759 & $-18 \%$ & 4595 & $19 \%$ & 80136 & $-16 \%$ \\
\hline 2010 & 923 & $-76 \%$ & 27742 & $-61 \%$ & 1683 & $-63 \%$ & 30348 & $-62 \%$ \\
\hline 2011 & 30 & $-97 \%$ & 17961 & $-35 \%$ & 909 & $-46 \%$ & 18900 & $-38 \%$ \\
\hline 2012 & 80 & $167 \%$ & 20030 & $12 \%$ & 1023 & $13 \%$ & 21133 & $12 \%$ \\
\hline 2013 & 36 & $-55 \%$ & 13872 & $-31 \%$ & 486 & $-52 \%$ & 14394 & $-32 \%$ \\
\hline 2014 & 38 & $6 \%$ & 17174 & $24 \%$ & 811 & $67 \%$ & 18023 & $25 \%$ \\
\hline 2015 & 1590 & 4 084\% & 21520 & $25 \%$ & 836 & $3 \%$ & 23946 & $33 \%$ \\
\hline 2016 & 1281 & $-19 \%$ & 22928 & $7 \%$ & 1222 & $46 \%$ & 25431 & $6 \%$ \\
\hline 2017 & 26127 & $1940 \%$ & 13999 & $-39 \%$ & 565 & $-54 \%$ & 40691 & $60 \%$ \\
\hline 2018 & 62622 & $140 \%$ & 17236 & $23 \%$ & 615 & $9 \%$ & 80473 & $98 \%$ \\
\hline 2019 & 25 & $-100 \%$ & 32794 & $90 \%$ & 271 & $-56 \%$ & 33090 & $-59 \%$ \\
\hline TOTAL & 135254 & & 1205987 & & 36955 & & 1378196 & \\
\hline$\%$ & $9,8 \%$ & & $87,5 \%$ & & $2,7 \%$ & & $100 \%$ & \\
\hline
\end{tabular}

Source: Elaborated by the authors, with data from Brasil (2020a).

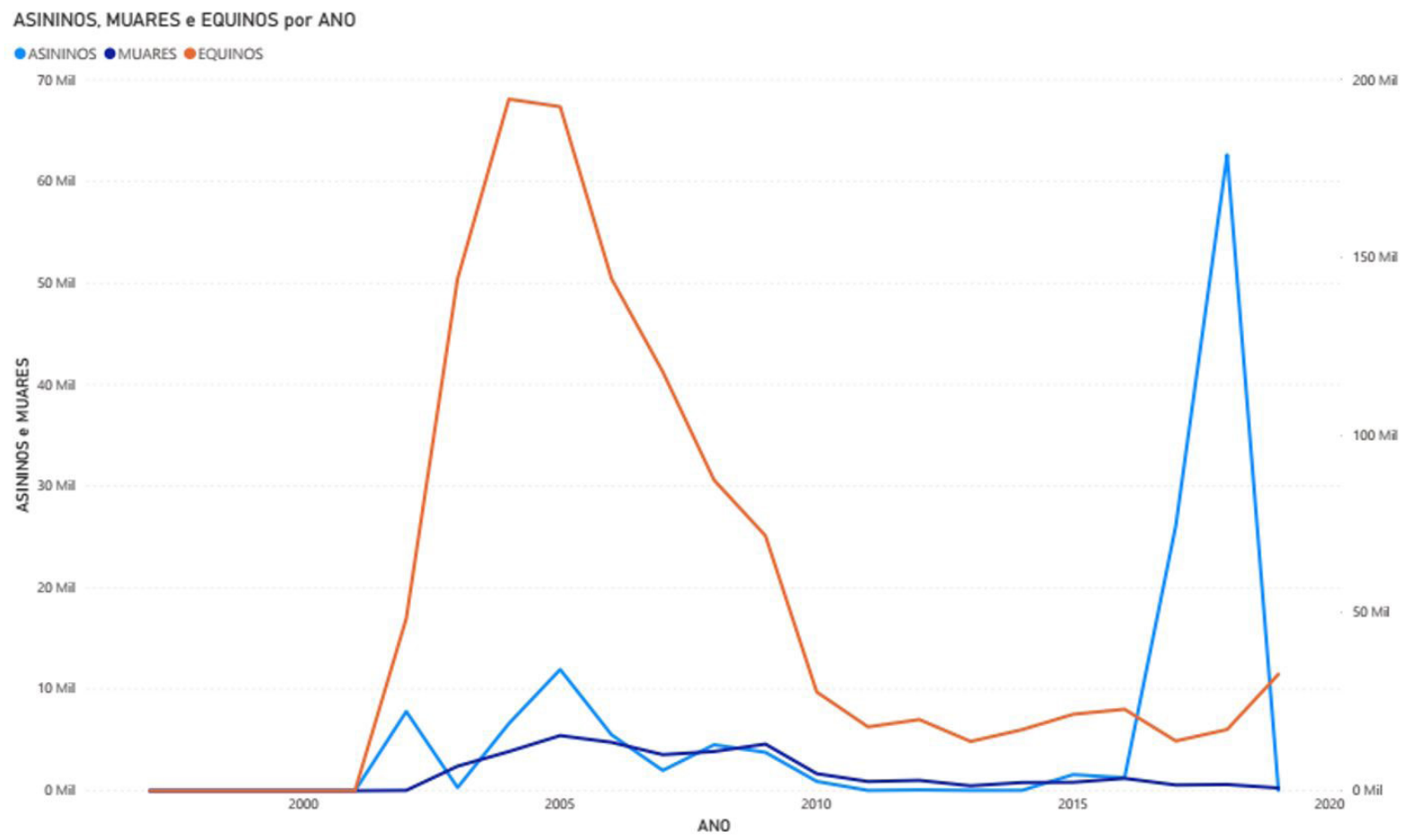

Figure 1 - The number of equids slaughtered in Brazil from 2002 to 2019. Source: Elaborated by the authors, with data from Brasil (2020a).

300,000 donkeys per year, which would "improve the local economy and solve the problem of donkeys surplus in the Northeast Brazil" (Agência O Globo, 2012). The issue attracted international attention and, in May 2012, the French actress and animal protector Brigitte Bardot addressed a letter to the then-president Dilma Rousseff, asking her to stop the shameful "animal genocide" of donkeys in Brazil (Giroux, 2012).

In 2015, during a business trip to China, the Minister of Agriculture Katia Abreu received a proposal from a Chinese investor, who said he would like to import one million donkeys from Brazil (Veja, 2015). Supposedly, donkeys are part of a much larger trade agreement between the 


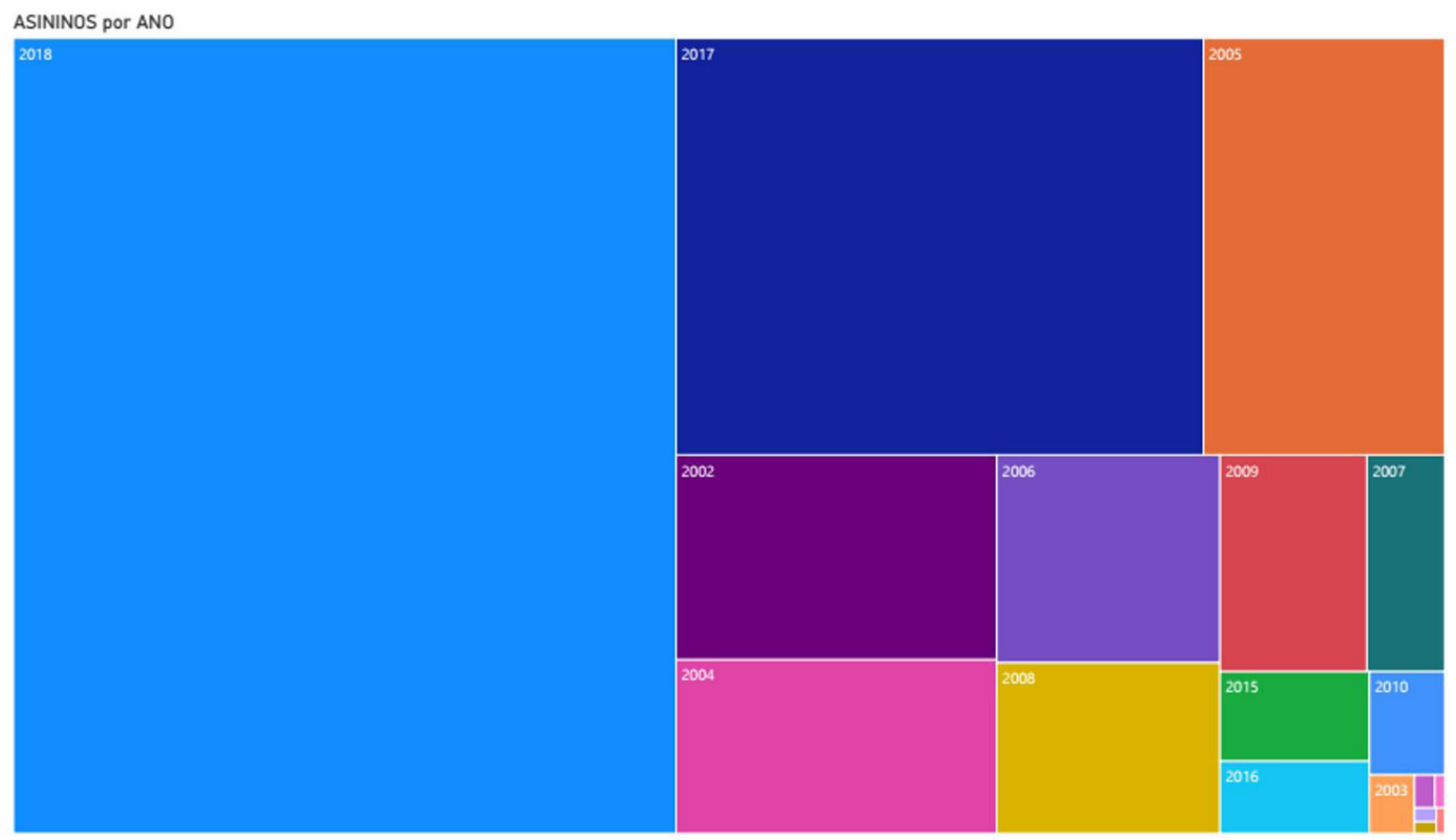

Figure 2 - The proportion of donkeys slaughtered by year, compared to the total amount (2002 to 2019). Source: Elaborated by the authors, with data from Brasil (2020a)

two countries, which included bovine, swine, and poultry meats, as well as other agricultural products.

In 2016, Bahia's Animal Health Agency published an official text ${ }^{2}$ that defines the criteria for equids slaughter under the State Inspection Service (SIE) (Agência de Defesa Agropecuária da Bahia, 2016). In the same year, a slaughterhouse started operating in Miguel Calmon/ BA (FrigoCezar) "to test the market". One year later, in July 2017, with the support of Bahia's governor Rui Costa, the same group from Miguel Calmon started operating at Amargosa/BA (Frinordeste), followed by two others at Simões Filho/BA (CabraForte) and Itapetinga/BA (Sudoeste), in December 2017 and August 2018, respectively (Buarque, 2019). Other Brazilian states also have slaughterhouses authorized to perform the activity, but their main business is horse meat (Table 3 ).

After repeated incidents of animal mistreatment ${ }^{3}$ were reported by the press, following denouncement from animal protection NGOs and local communities, a temporary ban on donkey slaughter was determined in Bahia by the end of November 2018, by judge Arali Maciel Duarte (1 ${ }^{\text {a }}$ Vara Federal, Salvador). The action was led by a coalition of civil society organizations: União Defensora dos Animais Bicho Feliz, Rede de Mobilização pela Causa Animal, Fórum Nacional de Proteção e Defesa Animal, SOS Animais de Rua, and Frente Nacional de Defesa dos Jumentos, who pointed out that donkey slaughter presents a potential threat

Portaria n. 255, de 29 de junho de 2016.

See other papers in this special issue, i.e. Farias et al. (2021). to the species conservation and risk of spreading zoonosis (Bittencourt, 2018). Besides, in many circumstances, the commercial exploitation of donkeys did not respect federal laws or instructions on animal transport and welfare (Bittencourt, 2018). It also fails to meet international requirements established by the World Organization for Animal Health (OIE) (Gameiro et al., under review). In September 2019, the ban was lifted by another juridical act signed by judge Kassio Marques (Tribunal Federal da $1^{\text {a }}$ Região, Bahia), who defended that the interruption of slaughter had caused serious damages to the order and the public economy since the activity is legal and generates jobs and income (Martines, 2019).

Since the relationship between donkeys and humans is constantly changing, agreeing on what is best for donkey welfare is not straightforward (McLean \& Navas Gonzalez, 2018). Objective and subjective conditions shape the perceptions people construct (and permanently reconstruct) about donkeys, therefore determining practical attitudes towards these animals (Gameiro et al., under review). Despite the valuable contributions donkeys have made toward society, particularly in developing regions, little is known about the proper care and management of this species, and their welfare is often neglected (McLean \& Navas Gonzalez, 2018). Moreover, moral, religious, and economic values are often in conflict when people reflect on the current role donkeys play in the Brazilian Northeast, causing symbolic representations to oscillate from a high appreciation of the cultural and historical heritage of donkeys to a disregard for 
Table 3 - Export-approved equids slaughterhouses in Brazil (as of July 2020)

\begin{tabular}{cccc}
\hline \multicolumn{4}{c}{ Export-approved equids (horses, donkeys and mules) slaughterhouses - SIF } \\
\hline Name & Location & Capacity & Status \\
\hline Frigorífico Regional Sudoeste LTDA & Itapetinga/BA & Up to 50 equids/hour & Opened and enabled to export \\
Frigorífico Floresta LTDA & São Gabriel/RS & Up to 30 equids/hour & Opened and enabled to export \\
Nordeste Pecuária, Indústria e Comércio LTDA & Amargosa/BA & 30 equids/hour & Opened and enabled to export \\
Frigorífico Prosperidad S/A & Araguari/MG & 30 to 50 equids/hour & Closed, but SIF is active \\
Cabra Forte Alimentos LTDA & Simões Filho/BA & 30 equids/hour & Closed, but SIF is active \\
Frigorífico União - Sapatini e Rodrigues Frig.LTDA & Apucarana/PR & Up to 30 equids/hour & Closed, but SIF is active \\
Frigorífico Santa Fé & Santa Fé/PR & & Closed \\
Frigorífico King Meat & Apucarana/PR & & Closed \\
Frigorífico Oregon & Apucarana/PR & & Closed \\
\hline
\end{tabular}

Source: Elaborated by the authors, with data from Brasil (2020a).

their lack of utility and the risk they potentially represent to human life (Gameiro et al., under review).

Since there is no donkey production chain in Brazil, slaughtered animals generally correspond to those who reached the end of their productive life (or are found roaming on roads, in case of ejiao production). This subject is sensible and raises concerns worldwide for different species, i.e. the controversy about the equine slaughter in the USA. The heat stress during the transport of horses for many hours and the injuries sustained when mixing strange horses were some of the critical points related to animal welfare and slaughter. After the interdiction of horse slaughter in the United States, the issue of the unwanted horse came up, with questions that were barely answered about who should care for and afford them (Lenz, 2009). Marginal uses of donkey products are related in Brazil (i.e. for the production of animal feed, buttons, art crafts), and a popular belief that beef jerky could be made of donkey or horse meat still prevails, but the Brazilian law obliges all the commercial food packages to accurately inform consumers about the origin of the product.

Tables 1 and 2 also present official figures on the slaughter of horses and mules in Brazil, for comparison. The slaughter of horses was high from 2002 to 2010 (114,275 animals per year, on average), when the European Union, which was then the main importer of Brazilian horse meat, established a new regulation ${ }^{4}$ on the traceability system for the production of horse meat to export. It included, among others, controls over the registration of holdings and animal identification, requiring that only horses with a known lifetime medical treatment history would be allowed to be exported to the EU (European Commission, 2010).

The EU's meat industry faced a scandal in 2013 when horsemeat wrongly labeled as beef was found in burgers, lasagna, and spaghetti Bolognese in the United Kingdom,

\footnotetext{
4 Regulation EU no 206/2010.
}

France, and Sweden, triggering public outrage. Recent findings indicate that donkey meat could also be present in adulterated food (Zhao et al., 2019). This scandal raised questions about the traceability of food, and the integrity of the meat supply chain, leading the EU to tighten its oversight of the food industry in Europe (Euractiv, 2017). In 2017, the EU suspended horsemeat imports from Brazil due to sanitary reasons, after a series of audits after the "Carne Fraca" operation (Lima, 2017).

According to official data, from 2011 to 2019, the slaughter of horses decreased to a yearly average of 19,724 animals, a drop of $83 \%$ between the average of the two periods. It is important to notice that in 2017, the horse slaughter in Brazil decreased by 39\% from the previous year, then recovered by $23 \%$ in 2018 (compared to 2017), and increased by $90 \%$ in 2019 (relative to 2018), when it reached the highest level of this decade. This increase is partially due to Bahia's slaughter of horses since the state was responsible for more than half of the Brazilian total number of horses slaughtered in 2019. Moreover, Bahia has not registered any horse slaughtered from 2011 to 2016; 25 horses were slaughtered in 2017; 708 in 2018, and 17,793 in 2019 (Table 1). The figure for 2019, the year when donkey slaughter was forbidden in the state, represents an increase of $2,413 \%$ compared to 2018 . For comparison, Bahia has officially recorded the slaughter of only two donkeys and three mules in 2019.

Reflecting a lower demand and the drop of horse slaughter after 2011 in Brazil, the exports of equids meat (Table 4) has also sharply decreased in the period. From 2002 to 2010, Brazil has shipped 14,295 tons of equid meat per year, on average. From 2011 to 2019, the annual exports dropped to 2,592 tons, on average, down by $82 \%$ in the comparison of these two average values. The average export price was 2.03 USD between 2002-2010 and 2.75 USD between 2011-2019, a $35 \%$ increase when the two averages are compared. Until 2010, Belgium, Japan, Italy, the Netherlands, and France 
Table 4 - Brazilian exports of equids meat from 2002 to 2019

\begin{tabular}{lccc}
\hline & FOB Price (USD) & Net weight (kg) & USD/kg \\
\hline 2002 & 21850709 & 18989546 & 1.15 \\
2003 & 24279034 & 18417389 & 1.32 \\
2004 & 31278343 & 20483755 & 1.53 \\
2005 & 34109441 & 19100836 & 2.10 \\
2006 & 33799729 & 16122991 & 2.44 \\
2007 & 31910205 & 13101952 & 2.81 \\
2008 & 27741740 & 9869623 & 2.53 \\
2009 & 23425895 & 9247060 & 2.63 \\
2010 & 8725494 & 3319618 & 3.30 \\
2011 & 6882215 & 2082342 & 2.85 \\
2012 & 6772386 & 2375961 & 2.92 \\
2013 & 5155993 & 1768209 & 3.14 \\
2014 & 6652099 & 2118395 & 2.71 \\
2015 & 7532706 & 2775222 & 2.85 \\
2016 & 7836267 & 2747298 & 2.30 \\
2017 & 7048224 & 3063143 & 2.26 \\
\end{tabular}

Source: Elaborated by the authors, with data from Brasil (2020b).

were the main importers of Brazilian equids meat. Russia and Vietnam appear as important importers after 2013 to become the two main importing countries in 2018 and 2019. China has officially imported Brazilian equids meat in 2015 and 2018, but the volume is not significant ${ }^{5}$. It is worth mentioning that horses accounted for $87.5 \%$ of all equid slaughters in Brazil from 2002 to 2019, whereas the donkeys' share was about $9.8 \%$ and mules, $2.7 \%$. Figure 3 shows the main destinations of Brazilian equid meat exports accumulated from 2002 to 2019.

Data exports of equids raw hides and skins (Table 5) show the instability of this unconsolidated market. The volume exported is most significant until 2006, as it is for the quantity of slaughtered animals, and starts to decrease sharply after 2007. From 2002 to 2010, about 7,354 tons of equids hides and skins were exported per year by Brazil, but the quantity drops to 18.3 tons/year from 2011 to 2020 . In 2019, the exports totaled 98.8 tons, an increase of 4,640\% from the previous year. This can be considered coherent with the growing number of slaughtered donkeys in 2017 and 2018.

\footnotetext{
The relationship between the commerce of donkeys skin and meat are, however, not difficult to find. Shandong Dong-E-E-Jiao Co Ltd, founded in 1952, is the largest Chinese ejiao maker by market share (Shandong, 2018). In 2015 , the company decided to invest in the food sector as well, signing an agreement to launch two food brands for donkey flesh. The company allegedly had a demand of 10 million donkey skins annually and, in face of the tight supply, planned to shift part of its business to deal with donkey fresh meat. As reported by the press, in a partnership with Shandong Lvbang, a donkey flesh developer and producer, the ejiao pharmaceutical company intended to open 3,000 donkey restaurants in China and globally, besides setting up 200 central kitchens in major cities, in a three-year period (Wenqian, 2015)
}

The Brazilian export prices of hides and skins also seem to reflect the valorization of these raw materials in the international market, a result of the growth in eijao production and prices, as discussed in the introduction of this paper. Table 5 indicates that the highest equid skin prices are found from 2015 on when considering the historical series beginning in 2002. The average export price was $9.02 / \mathrm{kg}$ USD of equid hide and skin in these five years (2015-2019), against 2.96 USD in the period 2002-2014, representing an increase of 204\%. Figure 4 shows the main destinations of Brazilian equids hides and skins exports, accumulated from 2002 to 2019. It is worth noting that other Asian countries, such as Hong Kong, are reported to import donkey skin for re-export to China.

Brazilian exports of live donkeys are presented in Table 6. Exports were mostly concentrated in the period from 2005 to 2010 (about 35 heads per year), with some activity in 2012 (19 heads). After years without exporting, the official figures indicate that Brazil shipped 9,329 live donkeys in 2019, by international airports located in the state of São Paulo (8 units to the United States and 9,321 to Mexico). The US is generally interested in donkey breeds of high-quality genetic material for crossbreeding. US imports reached 22,826 heads in 2002, but decreased to a few units in the following years; in 2018, the US imported 405 live donkeys (Food and Agricultural Organization of the United Nations, 2020). Mexico, in turn, is reported to be an important seller of donkey products to China, along with Peru and Egypt (Xinhua News Agency, 2017). FAO's most recent estimates show that Mexico hosts the 


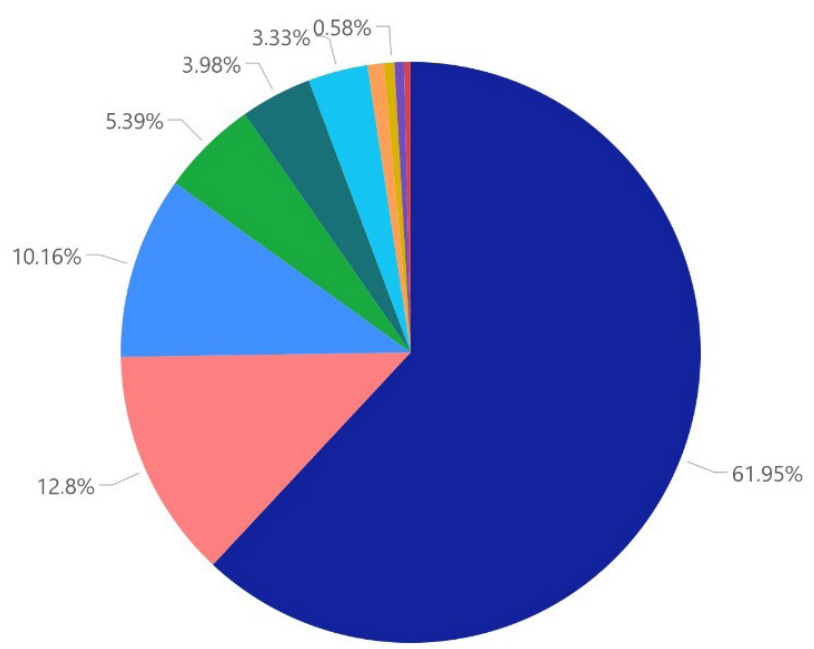

IMPORTING COUNTRY

- Belgium

- Vietnam

- Russia

- Japan

- Italy

- Netherlands

- South Africa

- Germany

- France

- Hong Kong

Figure 3 - Main destinations of Brazilian equids meat exports accumulated from 2002 to 2019. Source: Elaborated by the authors, with data from Brasil (2020b).

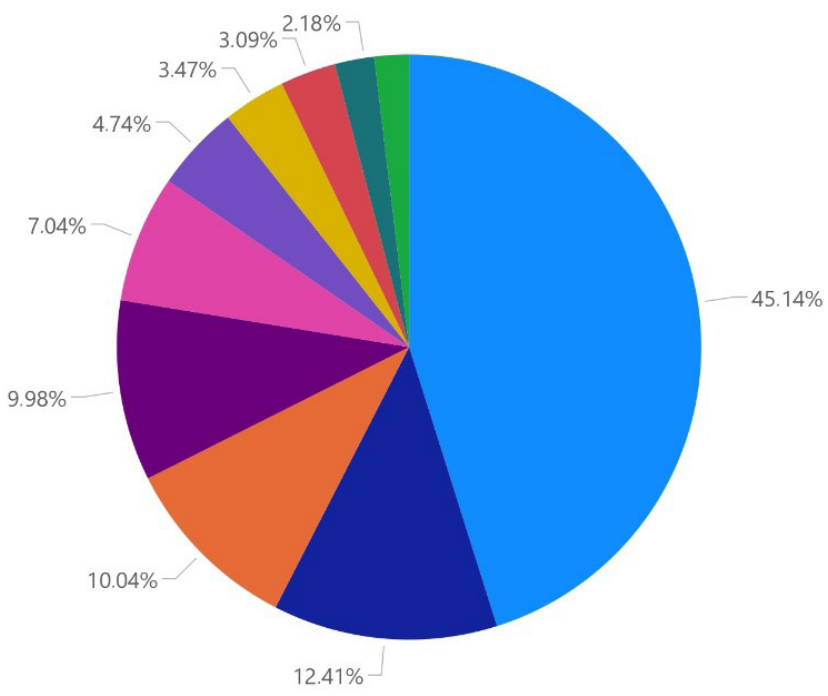

Importing country

-Italy

- Portugal

- Hong Kong

-Spain

- China

- United States

- Mexico

- Taiwan

- Singapore

- Netherlands

Figure 4 - Main destinations of Brazilian equids raw skins and hides exports accumulated from 2002 to 2019. Source: Elaborated by the authors, with data from Brasil (2020b).

Table 5 - Brazilian exports of equids raw skin and hides from 2002 to 2019

\begin{tabular}{cccc}
\hline & FOB Price (USD) & Net weight (kg) & USD/kg \\
\hline 2002 & 27545244 & 7071292 & 3.90 \\
2003 & 14135895 & 6470573 & 2.8 \\
2004 & 42156060 & 16500500 & 2.55 \\
2005 & 63820641 & 23251733 & 2.74 \\
2006 & 46675723 & 12710485 & 3.67 \\
2007 & 178655 & 42686 & 4.19 \\
2008 & 2561 & 469 & 5.46 \\
2009 & 7548 & 72872 & 0.10 \\
2010 & 124873 & 67283 & 1.86 \\
2011 & 36538 & 7601 & 4.81 \\
2012 & - & - & - \\
2013 & 18550 & 16200 & 1.15 \\
2014 & - & - & - \\
2015 & 296 & 16 & 18.50 \\
2016 & 26883 & 3070 & 8.76 \\
2017 & 3815 & 370 & 10.31 \\
2018 & 15415 & 2085 & 7.39 \\
\end{tabular}

Source: Elaborated by the authors, with data from Brasil (2020b). 
Table 6 - Brazilian exports of live donkeys from 2002 to 2019

\begin{tabular}{cccc}
\hline & FOB Price (USD) & Units (head) & USD/head \\
\hline 2002 & 6000 & 5 & 1200 \\
2003 & 2900 & 5 & 580 \\
2004 & 500 & 1 & 500 \\
2005 & 66951 & 40 & 1674 \\
2006 & 23433 & 29 & 774 \\
2007 & 24852 & 16 & 1553 \\
2008 & 309350 & 48 & 6445 \\
2009 & 35953 & 35 & 1027 \\
2010 & 385668 & 39 & 9889 \\
2011 & 1000 & 1 & 1000 \\
2012 & 33950 & 19 & 1786 \\
2013 & - & - & - \\
2014 & - & - & - \\
2015 & 15452 & 5 & - \\
2016 & - & - & - \\
2017 & - & 30 & 1.5 \\
2018 & 45 & 9329 & 1.70 \\
2019 & 15842 & &
\end{tabular}

Source: Elaborated by the authors, with data from Brasil (2020b).

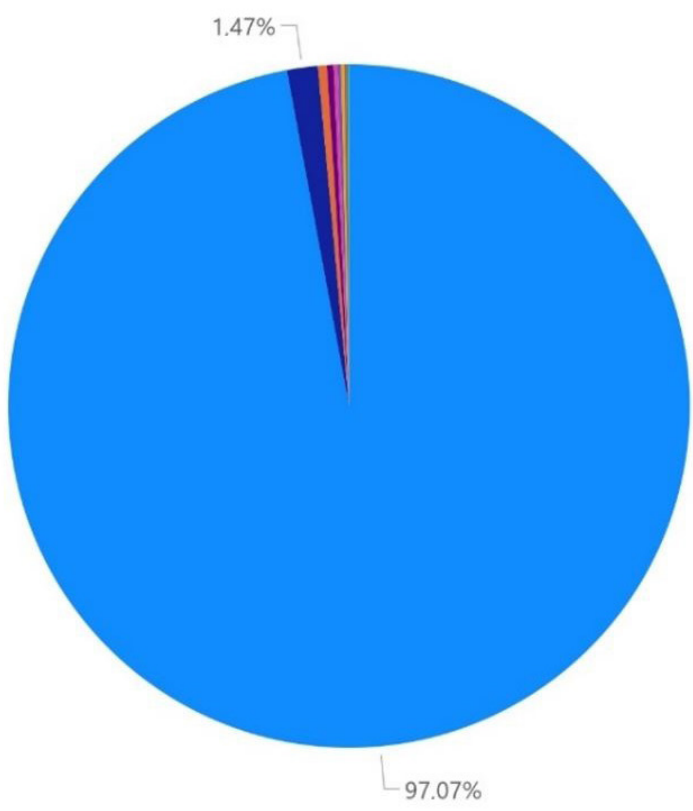

Importing Country
- Mexico
- Angola
- Venezuela
- United Kingdom
- Argentina
- Uruguay
- United States
- Congo
- Germany
- Panama
- Belgium

Figure 5 - Main destinations of Brazilian live donkeys exports accumulated from 2002 to 2019. Source: Elaborated by the authors, with data from Brasil (2020b).

world's fourth-largest donkey population, with more than 3.28 million animals in 2018, behind Ethiopia, Sudan, and Pakistan (Food and Agricultural Organization of the United Nations, 2020). Recently, the country has also become a leading importer of live donkeys, reaching 12,211 heads in $2017^{6}$ and ranking only behind China, while it exported only 8 heads (Food and Agricultural Organization of the United Nations, 2020).

FAO data regarding 2019 are not available, so that comparisons cannot be made with MDIC statistics.
The United Kingdom, Venezuela, Congo, Angola, and Uruguay also imported live donkeys from Brazil in the last decade. Figure 5 shows the main destinations of Brazilian live donkeys exports from 2002 to 2019. Generally, the exports of live donkeys are aimed for breeding or crossbreeding activities, as the commercial production of mules (hybrids) is valorized in several countries. The values of Brazilian exports (USD/head) are shown in Table 6 and can also be indicative of this market behavior, at least until 2015, as confirmed by market agents we interviewed. After that, the sharp drop in dollar prices (per head) and the high 
number of exported animals - coincidently, in the year that slaughter was banned for nine months in Brazil - might suggest other commercial purposes for Brazilian exported donkeys, although we cannot discard eventual incorrections in the source of the statistical series.

\section{Conclusions}

This paper aimed to present and analyze official data on donkey slaughter and donkey products exports (specifically equids meat and equids raw skins and hides exports) in Brazil, from 2002 to 2019. The paper also presents in parallel the business and political scenario that explains the apparent erratic nature of the commerce. A comparison to horses and mules was made, when possible and appropriate. We observed that, for Brazil, the international market for donkey products is not consolidated, which is reflected in the highly fluctuating figures found in our analysis.

Contrary to established markets (for example, beef, pork, and poultry meats), characterized by large and steady trade volumes and high liquidity (many buyers and sellers), the donkey trade is generally characterized by eventual business responding to market opportunities, variable volumes and a small diversity of importing countries. This scenario can lead to a predatory search for raw material in a precise time and place, threatening local "stocks", as we can see in the case of the Brazilian Northeast donkey aimed for the production of ejiao. Moreover, conflicting moral and economic values, as well as different perceptions about the roles donkeys play (or should play) in modern society, reflect on varied propositions about what is best for donkey welfare, and how to care for and manage the species.

To our knowledge, this is the first effort systematically focused on the presentation of official data about donkey slaughter and exports in Brazil. We expect that this analysis, combining quantitative and qualitative approaches, could provide a tangible dimension to the situation and contribute to the work of social actors dedicated to donkey issues in the country.

\section{Conflict of Interest}

The authors declare that there is no conflict of interest.

\section{Ethics Statement}

This article does not contain any studies with animals performed by any of the authors.

\section{Acknowledgements}

The authors acknowledge and thank the financial support from The Donkey Sanctuary and Fundação de Medicina Veterinária (Fumvet). The authors are also thankful for the collaboration of Detran-CE (Ceara State Department of Traffic) and Prof. Augusto Hauber Gameiro (VNP/FMVZ, University of São Paulo).

\section{References}

Agência de Defesa Agropecuária da Bahia - ADAB. Portaria n. 255, de 29 de junho de 2016. Diario Oficial do Estado [Internet], Salvador. 2016 Jul 6 [cited 2020 Aug 15]. Available from: http://www.adab.ba.gov.br/arquivos/File/ Port255Abatedeequideos.pdf.

Agência O Globo. Nordeste vai exportar jumentos para a China. Gazeta do Povo [Internet]; 2012 Mar 10 [cited 2020 Aug 12]. Available from: https://www.gazetadopovo. com.br/economia/nordeste-vai-exportar-jumentos-paraa-china-7mg3npbzmj8m3zgwm2qdiwk0e/.

Bennett R, Pfuderer S. The potential for new donkey farming systems to supply the growing demand for hides. Animals. 2020;10(4):718. http://dx.doi.org/10.3390/ani10040718. PMid:32326062.
Bittencourt M. Justiça proíbe o abate de jumentos na Bahia após casos de maus-tratos. Correio do Povo [Internet]; 2018 Dec 1 [cited 2020 Aug 11]. Available from: https:// www.correio24horas.com.br/noticia/nid/justica-proibe-oabate-de-jumentos-na-bahia-apos-casos-de-maus-tratos/.

Bowen GA. Document analysis as a qualitative research method. Qual Res J. 2009;9(2):27-40. http://dx.doi. org/10.3316/QRJ0902027.

Brasil. MAPA: Ministério da Agricultura, Pecuária e Abastecimento. Serviço de Inspeção Federal [Internet]. Brasília; 2020a June [cited 2020 June 16]. Available from. http://sigsif.agricultura.gov.br/primeira_pagina/extranet/ SIGSIF.html.

Brasil. MDIC: Ministério da Industria, Comércio Exterior e Serviços. MDIC Comex Stat [Internet]. Brasília; 2020b 
June [cited 2020 Jun 2]. Available from: http://comexstat. mdic.gov.br/pt/geral.

Buarque SM. Brazil's ban on donkey slaughter halts trade with China. China Dialogue [Internet]; 2019 July 2 [cited 2020 Aug 18]. Available from: https://chinadialogue.net/ en/business/11338-brazil-s-ban-on-donkey-slaughterhalts-trade-with-china/.

Burn CC, Dennison TL, Whay HR. Environmental and demographic risk factors for poor welfare in working horses, donkeys and mules in developing countries. Vet J. 2010;186(3):385-92. http://dx.doi.org/10.1016/j. tvjl.2009.09.016. PMid:19926316.

Camillo F, Rota A, Biagini L, Tesi M, Fanelli D, Panzani D. The current situation and trend of donkey industry in Europe. J Equine Vet Sci. 2018;65:44-9. http://dx.doi. org/10.1016/j.jevs.2017.11.008.

Carneiro GF, Lucena JEC, Barros LO. The current situation and trend of the Donkey Industry in South America. J Equine Vet Sci. 2018;68:106-10. http://dx.doi.org/10.1016/j. jevs.2018.03.007.

Euractiv. EU says Brazil must 'restore trust' in meat exports. Euractiv [Internet]; 2017 Mar 28 [cited 2020 Aug 18]. Available from: https://www.euractiv.com/section/agriculture-food/ news/eu-says-brazil-must-restore-trust-in-meat-exports/.

European Commission. Regulation EU n. 206/2010 [Internet]. Official Journal, Brussels; 2010 Mar. 12 [cited 2020 Aug 19], L 073:1. Available from: https://eur-lex.europa.eu/ legal-content/EN/TXT/PDF/?uri=CELEX:02010R020620131115\&from $=$ FR.

Food and Agricultural Organization of the United Nations - FAO. Statistical Database Website [Internet]. Rome: FAO; 2020 [cited 31 Aug 2020]. Available from: http://www.fao. org/faostat/en/\#data/QA.

Farias SS, Gameiro MBP, Montechese ACD, Bernardino T, Oliveira CAA, Zanella AJ. Case report: the use of the AWIN welfare assessment protocol to monitor a group of abandoned donkeys. Braz J Vet Res Anim Sci. 2021;58(special issue):e174701. http://dx.doi.org/10.11606/issn.1678-4456. bjvras.2021.174701.

Fernandes K. Jumentos vão virar comida na mesa de estrangeiros. Folha de São Paulo [Internet]; 2004 May 5 [cited 2020 Aug 11]. Available from: https://wwwl.folha.uol. com.br/folha/dimenstein/cbn/comunidade_050504.shtml.
G1 PE. Abatedouro clandestino que comercializava carne de jumento é interditado no Grande Recife; 2017 Jun 16. G1 PE [Internet]; [cited 2020 Aug 13]. Available from: https://g1.globo.com/pernambuco/noticia/abatedouroclandestino-que-comercializava-carne-de-jumento-einterditado-no-grande-recife.ghtml.

Gameiro MBP, Clancy C, Zanella AZ. Between freedom and abandonment: social representations of free-roaming donkeys in the Brazilian Northeast. Anthrozoos. Under review.

Giroux A. Brigitte Bardot dénonce le "génocide des ânes" au Brésil. L'Express [Internet], 2012 May 25 [cited 2020 Aug 11]. Available from: https://www.lexpress.fr/styles/ vip/brigitte-bardot-denonce-le-genocide-des-anes-aubresil_1118714.html.

Leitão G. Sua excelência, o jumento. Fortaleza: Expressão Gráfica e Editora; 2016. 300 p.

Lenz TR. The unwanted horse in the United States: an overview of the issue. J Equine Vet Sci. 2009;29(5):253-8. http://dx.doi.org/10.1016/j.jevs.2009.04.001.

Li X, Shi F, Gong L, Hang B, Li D, Chi L. Species-specific identification of collagen components in Colla corii asini using a nano-liquid chromatography tandem mass spectrometry proteomics approach. Int J Nanomedicine. 2017;12:4443-54. http://dx.doi.org/10.2147/IJN.S136819. PMid:28670118.

Lima S. Abate de cavalos é cada vez mais raro. Jornal do Comércio [Internet], 2017 Sep 18 [cited 2020 Aug 13]. Available from: https://www.jornaldocomercio.com/_ conteudo/2017/09/economia/585976-abate-de-cavalose-cada-vez-mais-raro.html.

Martines F. TRF-1 suspende decisão que proibia o abate de jumentos na Bahia. Consultor Jurídico [Internet]; 2019 Oct 5 [cited 2020 Aug 11]. Available from: https://www.conjur. com.br/2019-out-05/fimde-trf-suspende-decisao-proibiaabate-jumentos-bahia\#: :text=Em\%20novembro\%20de\%20 2018\%2C\%20a,casos\%20de\%20maus\%2Dtratos\%20animais.

McLean AK, Navas Gonzalez FJ. Can scientists influence donkey welfare? Historical perspective and a contemporary view. J Equine Vet Sci. 2018;65:25-32. http://dx.doi. org/10.1016/j.jevs.2018.03.008.

NE10. Brasil e China fazem acordo para exportar jumentos. JCPM/UOL [Internet]; 2012 Apr 26 [cited 2020 Aug 12]. Available from: https://ne10.uol.com.br/canal/noticias/ 
brasil/noticia/2012/04/26/brasil-e-china-fazem-acordopara-exportar-jumentos-339612.php.

Queiroz MR, Gameiro MBP, Zanella AJ. The population of donkeys and mules in Brazil according to agricultural censuses from 1960 to 2017. Braz J Vet Res Anim Sci. 2021;58(special issue):e174365. http://dx.doi.org/10.11606/ issn.1678-4456.bjvras.2021.174365.

Veja [Internet]. São Paulo: Grupo Abril; [2020]. 'Jumento tipo exportação' renderia US $\$ 3$ bilhões ao Brasil; 2015 Nov 19 [cited 2020 Aug 11]. Available from: https://veja.abril. com.br/economia/jumento-tipo-exportacao-renderia-us3-bilhoes-ao-brasil/.

Diario do Nordeste [Internet]. Fortaleza; [2020]. Ceará inicia exportação de jumentos; 2004 May 1 [cited 2020 Aug 12]. Available from: https://diariodonordeste.verdesmares.com. br/regiao/ceara-inicia-exportacao-de-jumentos-1.4651.

Salles PA, Sousa LO, Gomes LPB, Barbosa VV, Medeiros GR, Sousa CM, Weller M. Analysis of the population of equidae in semiarid region of Paraíba. J Biotechnol Biodivers. 2013;4(3):269-75. http://dx.doi.org/10.20873/ jbb.uft.cemaf.v4n3.salles.

Shandong. Donge Ejiao joins hands with Korean Ginseng Corp. China Daily [Internet], 2018 Nov 27 [cited 2020 Aug 18]. Available from: http://shandong.chinadaily.com. cn/2018-11/27/c_294501.htm.
Suarez J. Sob a pele do jumento. Reporter Brasil [Internet]; 2019 Dec 11 [cited 2020 Aug 13]. Available from: https:// reporterbrasil.org.br/2019/12/sob-a-pele-do-jumento.

The Donkey Sanctuary. Under the skin: update on the global crisis for donkeys and the people who depend on them [Internet]. Sidmouth (UK); 2019 Nov. 31 p. Available from: https://www.thedonkeysanctuary.org.uk/sites/uk/ files/2019-11/under-the-skin-report-revised-2019.pdf.

Wenqian Z. Donge Ejiao Pharmaceutical to launch donkey food brands.China Daily [Internet]; 2015 Dec 17 [cited 2020 Aug 18]. Available from: http://www.chinadaily.com. cn/business/2015-12/17/content_22734077.htm.

Xinhua News Agency. China cuts tariff on donkey hides. CGTN Business [Internet]; 2017 Dec 31 [cited 2020 Aug 18]. Available from: https://news.cgtn.com/ news/3067444d35637a6333566d54/index.html.

Zhao L, Hua MZ, Li S, Liu J, Zheng W, Lu X. Identification of donkey meat in foods using species-specific PCR combined with lateral flow immunoassay. RSC Advances. 2019;9(46):26552-8. http://dx.doi.org/10.1039/C9RA05060D.

Financial Support: The Donkey Sanctuary and Fundação de Medicina Veterinária (Fumvet). 